\title{
Magnification and Shrub Stemmy Material Influen- ces on Fecal Analysis Accuracy
}

\author{
JERRY L. HOLECHEK AND RAUL VALDEZ
}

\begin{abstract}
When 100X and 200X microscope magnification levels were used singly and interchangeably in microhistological analysis, magnification level had no effect $(P<.05)$ on diet botanical composition of $60 \%$ grass and $60 \%$ forb diets containing 6 forage species fed to mule deer. However, large differences occurred between magnification levels for individual plant species in a $60 \%$ shrub diet containing the same forage species. The use of the $100 \mathrm{X}$ and $200 \mathrm{X}$ magnification levels interchangeably was slightly more accurate than exclusive use of either magnification level for the high grass and high shrub diets. For fecal analysis our study shows $100 \mathrm{X}$ and $200 \mathrm{X}$ microscope magnification levels can be used singly or interchangeably with little influence on accuracy. Use of the $100 \mathrm{X}$ magnification level to scan fields for potentially identifiable fragments followed by switching to $200 \mathrm{X}$ magnification for better resolution of fragments difficult to discern can slightly improve both speed and accuracy. Fourwing saltbush, which had a high proportion of stemmy material relative to leaves, was severely underestimated in the feces of all 3 diets. Our data indicate fecal analysis has limited value as an estimator of diets of herbivores, such as mule deer, that consume significant but variable quantities of stemmy material from shrubs.
\end{abstract}

Fecal analysis has become one of the most widely used tools to evaluate the botanical composition of wild herbivore diets. While degree of magnification in fecal analysis studies has consistently been $100 \mathrm{X}$ or $125 \mathrm{X}$, higher levels of magnification might improve the accuracy of fecal analysis. Fecal analysis may have severe limitations for estimating diets of herbivores consuming varying quantities of woody material during the year (Zyznar and Urness 1969, Westoby et al. 1976). The objectives of this research were to determine the similarity between actual mule deer diets and fecal samples when the $100 \mathrm{X}$ and $200 \mathrm{X}$ microscope magnification levels were used singly and interchangeably for estimating the botanical composition of fecal samples. Because the 3 diets used in this study contained different levels of shrub stemmy material, its influence on fecal analysis accuracy could be evaluated.

\section{Methods}

Three trials were conducted at New Mexico State University with 2 individually penned mule deer does in summer, 1982. Each deer was individually fed 3 diets that were $60 \%$ by weight grasses, forbs, and shrubs (Table 1). Commercial forages in the diets were sudan grass (Sorghum sudanense), timothy (Phleum pratense), and alfalfa (Medicago sativa). Native forages fed were mountain mahogany (Cercocarpus montanus), fourwing saltbush (Atriplex canescens), and soft globemallow (Sphaeralcea incana). Current year's growth from native plants was collected near the Organ Mountains between $6 \mathrm{July}$ and 8 August 1982 . Fourwing saltbush was purposely clipped to contain a much higher proportion of stemmy material than mountain mahogany. Native forages were sun dried for 5 days and then chopped to reduce particle size $1-2 \mathrm{~cm}$ to prevent mule deer from selecting plant species or parts from

\footnotetext{
Authors are associate professors, Department of Animal and Range Sciences and Department of Fishery and Wildlife Sciences, New Mexico State University, Las Cruces 88003 .

This is Journal Article 1076, Agr. Exp. Sta., New Mexico State University, Las Cruces 88003 .

Manuscript accepted October 18, 1984.
}

mixtures. Each diet was fed to each deer for 12 days. All defecations from each deer were collected and composited during the last day of each trial. During this period the pens were covered with a canvas mat to prevent contamination of feces.

Samples of the 3 diets fed and the feces were dried in a forced air oven and then ground through a micro-wiley mill with a $1-\mathrm{mm}$ screen. Before slide preparation all diet and fecal sample materials were soaked in undiluted domestic bleach for 15 minutes.

Ten slides were prepared using Hoyer's solution from each undigested diet sample and for each fecal sample. Three trained observers evaluated the 10 slides for each diet sample at $100 \mathrm{X}$ magnification. To insure high repeatability, 20 frequency observations were recorded per slide (Holechek and Vavra 1981). Fecal samples were evaluated at $100 \mathrm{X}$ and $200 \mathrm{X}$ magnification. A third procedure was used for fecal samples that involved scanning or fields at $100 \mathrm{X}$ magnification for potentially identifiable fragments followed by switching to $200 \mathrm{X}$ magnification for better resolution of fragments difficult to identify. Cellular material had to be present before a fragment was considered identifiable by observers. This helped prevent overestimation of soft globemallow, that has many easily identifiable trichomes. The frequency addition procedure (Holechek and Gross 1982) was used to calculate percent by weight composition of each diet.

Multivariate analysis of variance (MANOVA) was used to determine if a difference in botanical composition existed between the observed diet offered and fecal samples for that diet read at the $100 \mathrm{X}, 200 \mathrm{X}$, and $100 \mathrm{X} / 200 \mathrm{X}$ interchangeable magnification levels. Individual observer (3) estimates for each deer (2) were used as replications (6) and the 6 species in the 3 diets were used as variates in this analysis. Stroup and Stubbendieck (1983) discuss the use of MANOVA for determining differences in botanical composition. The degree of similarity in botanical composition between actual, observed undigested, and fecal samples was calculated with Kulcyznski's formula (Oosting 1956). The similarity value represents the percentage of the 2 mixtures compared that is identical.

\section{Results and Discussion}

MANOVA showed botanical compositions of observed undigested and fecal samples differed $(P<.05)$ for the high shrub diet at all magnification levels (Table 2). Soft globemallow and fourwing saltbush in the high shrub diet showed large differences between observed undigested diets and fecal samples (Table 1). Undigested and fecal samples for the high grass and high forb diets did not differ $(P>.05)$ at any magnification level. Observed undigested samples represented the botanical composition of the actual diets better than the feces for the high grass and high shrub diets (Table 2). However, the feces were most representative of the actual diet for the high forb diet.

Timothy was overestimated while fourwing saltbush was underestimated in all 3 observed diets compared to the actual diets. Fourwing saltbush was much more severely underestimated in fecal than undigested diet samples. The degree of under- or overestimation of timothy and fourwing saltbush was not consistent between diets. This is explained in part by observer variability (Table 3). In addition associative effects within feeds may have caused fragments of the 6 species to be digested differently between 


\begin{tabular}{|c|c|c|c|c|c|c|c|c|c|}
\hline \multirow[t]{2}{*}{ Diet } & \multirow[t]{2}{*}{$\begin{array}{l}\text { Actual } \\
\text { diet }\end{array}$} & \multicolumn{2}{|c|}{$\begin{array}{c}\text { Observed composition } \\
\text { of undigested } \\
\text { diet } \\
\text { using } 100 \mathrm{X} \\
\text { magnification }\end{array}$} & \multicolumn{2}{|c|}{$\begin{array}{c}\text { Observed composition } \\
\text { of } \\
\text { feces }(100 \mathrm{X} \\
\text { magnification) }\end{array}$} & \multicolumn{2}{|c|}{$\begin{array}{c}\text { Observed composition } \\
\text { of } \\
\text { feces }(200 \mathrm{X} \\
\text { magnification) }\end{array}$} & \multicolumn{2}{|c|}{$\begin{array}{c}\text { Observed composition } \\
\text { of } \\
\text { feces }(100 \mathrm{X} / 200 \mathrm{X} \\
\text { interchangeable) }\end{array}$} \\
\hline & & $\bar{x}$ & SE & $\bar{x}$ & SE & $\bar{x}$ & SE & $\bar{x}$ & SE \\
\hline \multicolumn{10}{|l|}{ High Grass } \\
\hline Timothy & 30 & 35 & 3.5 & 39 & 2.2 & 39 & 2.3 & 38 & 2.8 \\
\hline Sudan & 30 & 22 & 2.3 & 23 & 4.4 & 25 & 1.5 & 24 & 5.6 \\
\hline Soft globemallow & 10 & 17 & 2.2 & 16 & 7.8 & 9 & 4.4 & 14 & 7.2 \\
\hline Alfalfa & 10 & 13 & 2.0 & 9 & 0.9 & 16 & 4.6 & 10 & 2.0 \\
\hline Fourwing saltbush & 10 & 5 & 1.5 & 2 & 0.3 & 1 & 1.3 & 4 & 0.9 \\
\hline Mountain mahogany & 10 & 8 & 1.3 & 11 & 7.9 & 11 & 3.0 & 11 & 3.7 \\
\hline \multicolumn{10}{|l|}{ High Forb } \\
\hline Timothy & 10 & 16 & 1.7 & 14 & 2.0 & 14 & 0.3 & 16 & 5.4 \\
\hline Sudan & 10 & 7 & 3.8 & 9 & 2.0 & 8 & 0.6 & 10 & 3.8 \\
\hline Soft globemallow & 30 & 39 & 5.5 & 34 & 10.6 & 38 & 9.0 & 34 & 9.6 \\
\hline Alfalfa & 30 & 31 & 2.6 & 28 & 5.4 & 32 & 4.3 & 31 & 7.2 \\
\hline Fourwing saltbush & 10 & 3 & 1.2 & 2 & 2.8 & 1 & 1.0 & 1 & 0.7 \\
\hline Mountain mahogany & 10 & 3 & 2.3 & 12 & 2.7 & 8 & 4.5 & 8 & 2.6 \\
\hline \multicolumn{10}{|l|}{ High shrub } \\
\hline Timothy & 10 & 17 & 2.7 & 16 & 4.1 & 19 & 3.0 & 19 & 2.4 \\
\hline Sudan & 10 & 7 & 3.2 & 11 & 4.9 & 7 & 1.7 & 14 & 4.2 \\
\hline Soft globemallow & 10 & 14 & 3.1 & 32 & 9.5 & 15 & 6.4 & 18 & 8.0 \\
\hline Alfalfa & 10 & 10 & 2.9 & 10 & 1.0 & 10 & 2.3 & 17 & 2.6 \\
\hline Fourwing saltbush & 30 & 21 & 3.5 & 4 & 1.3 & 4 & 2.3 & 5 & 1.4 \\
\hline Mountain mahogany & 30 & 31 & 5.6 & 27 & 9.8 & 44 & 2.0 & 24 & 5.1 \\
\hline
\end{tabular}

'Botanical compositions of some treatments do not add to 100 due to rounding off.

Table 2. Percent similarity between actual and observed botanical compositions of 3 diets fed to mule deer.

\begin{tabular}{|c|c|c|c|c|c|}
\hline \multirow[b]{2}{*}{ Comparison' } & \multicolumn{5}{|c|}{ Diet } \\
\hline & $\begin{array}{l}\text { High } \\
\text { grass }\end{array}$ & $\begin{array}{l}\text { High } \\
\text { forb }\end{array}$ & $\begin{array}{l}\text { High } \\
\text { shrub }\end{array}$ & 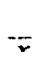 & $\bar{x}$ \\
\hline Actual/feces $(100 \mathrm{X} / 200 \mathrm{X})$ & 88 & 89 & $74 * *$ & & 84 \\
\hline Actual/feces $(100 \mathrm{X})$ & $85^{*}$ & 89 & $71^{* *}$ & & 82 \\
\hline Actual/feces $(200 \mathrm{X})$ & $84^{*}$ & 87 & $71^{* *}$ & & 81 \\
\hline Actual/undigested & $85^{*}$ & 83* & 88 & & 85 \\
\hline Undigested / feces $(100 \mathrm{X} / 200 \mathrm{X})$ & 94 & 92 & $77 *$ & & 88 \\
\hline Undigested / feces (100X) & 92 & 88 & $78^{*}$ & & 86 \\
\hline Undigested/feces $(200 \mathrm{X})$ & 88 & 94 & 83* & & 88 \\
\hline
\end{tabular}

'Data pooled across observers were used for calculation for similarity indices. * Diets are different $(P<.05)$ using MANOVA.

**Diets are different $(P<.01)$ using MANOVA.

the 3 feeds. Norris (1943) found that proportions of other species in the diet of sheep affected the extent to which a particular species was digested. Clippings of fourwing saltbush contained a higher proportion of stemmy material than mountain mahogany. Stems from shrubs have lower proportions of identifiable epidermal material per unit weight than grasses and forbs (Zyznar and Urness 1969, Westoby et al. 1976). Although other investigators (Vavra et al. 1978, Westoby et al. 1976, McInnis et al. 1983) have reported fecal analysis overestimated grasses and underestimated forbs and shrubs, our results indicate generalizations cannot be made. Our results are consistent with Zyznar and Urness (1969), Westoby et al. (1976), and Gill et al. (1983) in showing that fecal analysis severely underestimates shrubs high in stemmy material when they occur in the same diet with grasses and forbs.

MANOVA showed that the $100 \mathrm{X}, 200 \mathrm{X}$, and $100 \mathrm{X} / 200 \mathrm{X}$ interchangeable magnification levels differed $(P<.05)$ only for the high shrub diet (Table 1). The similarity between the actual and estimated botanical compositions was nearly the same for both the
$100 \mathrm{X}$ and 200X magnification levels for the 3 diets (Table 2). However, for the high grass and high shrub diets, the $100 \mathrm{X} / 200 \mathrm{X}$ interchangeable level estimated the actual diet more closely than the $100 \mathrm{X}$ or $200 \mathrm{X}$ levels.

Observers were most consistent in their estimates of grasses and least consistent in their estimates of shrubs (Tables 1 and 3). Mean similarity indices for the 3 individual observers were 78, 79, and $91 \%$, respectively, for actual compared to undigested diets; 70, 75, and $76 \%$, respectively, for actual diets compared to estimates of fecal composition; and 90,82 , and $83 \%$, respectively, for estimates of botanical composition of undigested diets compared to estimates of fecal composition. Holechek et al. (1982), Gross et al. (1983), and our study show observer variability is substantial when microhistological analysis is used. Our data show that variability is greater for fecal than undigested samples.

Observers found it much more difficult to identify fecal fragments than undigested fragments. Fecal fragments of alfalfa were more difficult to discern than those of other species. Observers did believe that they could more quickly identify alfalfa fragments with the $200 \mathrm{X}$ compared to $100 \mathrm{X}$ magnification level. Our data show that using $100 \mathrm{X}$ magnification to locate potentially identifiable fragments in microscope fields and then switching to the $200 \mathrm{X}$ magnification level for better resolution may slightly improve accuracy and speed.

Although only 6 species were used in this study, they do represent the plant types that can show differing responses to digestion. These include cool-season grasses (timothy) and warm-season grasses (sudan); easily identifiable shrubs (mountain mahogany) and easily identifiable forbs with many trichomes (soft globemallow) (Gill et al. 1983); legumes thought to be difficult to discern and highly sensitive to digestion and sample preparation (alfalfa) (Mclnnis et al. 1983, Gill et al. 1983); and shrubs with a high proportion of stemmy material (fourwing saltbush) (Westoby et al. 1976, Gill et al. 1983). Because of the types of species we selected and their levels in the 3 diets, we believe our results have application to herbivores selecting a wider variety of forages and different 
Table 3. Observer estimates of undigested and fecal samples pooled across magnification levels1.

\begin{tabular}{|c|c|c|c|c|c|c|c|c|c|}
\hline \multirow[b]{2}{*}{ Diet } & \multirow[b]{2}{*}{ Actual diet } & \multicolumn{4}{|c|}{ Undigested samples } & \multicolumn{4}{|c|}{ Fecal samples } \\
\hline & & $\begin{array}{c}\text { Obs. } \\
1\end{array}$ & $\begin{array}{c}\text { Obs. } \\
2 \\
\end{array}$ & $\begin{array}{c}\text { Obs. } \\
3\end{array}$ & $\bar{x}$ & $\begin{array}{c}\text { Obs. } \\
1\end{array}$ & $\begin{array}{c}\text { Obs. } \\
2\end{array}$ & $\begin{array}{c}\text { Obs. } \\
3\end{array}$ & $\bar{x}$ \\
\hline \multicolumn{10}{|l|}{ High Grass } \\
\hline Timothy & 30 & 35 & 41 & 29 & 35 & 39 & 42 & 34 & 39 \\
\hline Sudan & 30 & 20 & 20 & 27 & 22 & 21 & 22 & 30 & 24 \\
\hline Soft globemallow & 10 & 20 & 19 & 13 & 17 & 18 & 17 & 3 & 13 \\
\hline Alfalfa & 10 & 16 & 9 & 13 & 13 & 15 & 8 & 12 & 12 \\
\hline Fourwing saltbush & 10 & 3 & 5 & 8 & 5 & 2 & 0 & 4 & 2 \\
\hline Mountain mahogany & 10 & 6 & 6 & 10 & 8 & 6 & 10 & 18 & 11 \\
\hline \multicolumn{10}{|l|}{ High Forb } \\
\hline Timothy & 10 & 18 & 13 & 18 & 16 & 16 & 8 & 19 & 14 \\
\hline Sudan & 10 & 6 & 1 & 14 & 7 & 9 & 7 & 12 & 9 \\
\hline Soft globemallow & 30 & 38 & 49 & 30 & 39 & 41 & 48 & 16 & 35 \\
\hline Alfalfa & 30 & 31 & 35 & 26 & 31 & 24 & 31 & 32 & 30 \\
\hline Fourwing saltbush & 10 & 5 & 1 & 4 & 3 & 1 & 0 & 5 & 2 \\
\hline Mountain mahogany & 10 & 1 & 1 & 8 & 3 & 7 & 6 & 15 & 9 \\
\hline \multicolumn{10}{|l|}{ High Shrub } \\
\hline Timothy & 10 & 22 & 14 & 14 & 17 & 21 & 12 & 21 & 18 \\
\hline Sudan & 10 & 7 & 2 & 13 & 7 & 9 & 8 & 19 & 12 \\
\hline Soft globemallow & 10 & 20 & 12 & 10 & 14 & 30 & 32 & 3 & 22 \\
\hline Alfalfa & 10 & 15 & 5 & 9 & 10 & 13 & 11 & 11 & 12 \\
\hline Fourwing saltbush & 30 & 15 & 27 & 21 & 21 & 4 & 3 & 7 & 5 \\
\hline Mountain mahogany & 30 & 21 & 40 & 33 & 31 & 23 & 35 & 40 & 33 \\
\hline
\end{tabular}

'Botanical compositions for some observer/diet combinations do not add to 100 due to rounding off.

forage species. We conclude that the $100 \mathrm{X}$ and $200 \mathrm{X}$ magnification levels used interchangeably can slightly increase the accuracy of fecal analysis. When herbivore diets contain varying proportions of shrub stemmy material, we conclude that fecal analysis has limited value as an estimator of diet botanical composition. We doubt that reliable correction factors can be developed to improve fecal estimates of shrubs high in stemmy material because the proportion of shrub leaf to stem selected varies constantly within and between shrub species with seasonal change.

\section{Literature Cited}

Gill, R.B., L.H. Carpenter, R.M. Bartmann, D.L. Baker, and G.G. Schoonveld. 1983. Fecal analysis to estimate mule deer diets. J. Wildl. Manage. 47:902-915.

Gross, B.D., E. Mahgoub, and J.L. Holechek. 1983. Mastication effects on cattle diet determined by microhistological analysis. J. Range Manage. 36:475-476.

Holechek, J.L., and B.D. Gross. 1982. Evaluation of different calculation proced ures for microhistological analysis. J. Range Manage. 35:721-723.
Holechek, J.L., B.D. Gross, S.M. Dabo, and T. Stephenson. 1982. Effects of sample preparation, growth stage and observer on microhistological analysis of herbivore diets. J. Wildl. Manage. 46:502-505.

Holechek, J.L., and M. Vavra. 1981. The effect of slide and frequency observation numbers on the precision of microhistological analysis. $J$. Range Manage. 34:337-338.

McInnis, M.L., M. Vavra, and W.C. Krueger. 1983. A comparison of four methods used to determine the diets of large herbivores. J. Range Manage. 36:302-307

Norris, J.J. 1943. Botanical analysis of stomach contents as a method of determining forage consumption of range sheep. Ecology. 24:244-251.

Oosting, H.J. 1956. The Study of Plant Communities. W.H. Freeman Co. San Francisco, Calif.

Stroup, W.W., and J. Stubbendieck. 1983. Multivariate statistical methods to determine changes in botanical composition. J. Range Manage 36:208-212.

Vavra, M., R.W. Rice, and R.M. Hansen. 1978. A comparison of esophageal fistula and fecal material to determine steer diets. J. Range Manage. 31:11-13

Westoby, M., G.R. Rost, and J.A. Weis. 1976. Problems with estimating herbivore diets by microhistologically identifying plant fragments from stomachs. J. Mammalogy. 57:167-172.

Zyznar, E., and P.J. Urness. 1969. Qualitative identification of forage remnants in deer feces. J. Wildl. Manage. 33:506-510. 